\title{
The Differential Impact of Financial Intermediation on Economic Growth in Oil-Dependent Economies
}

\author{
ANTHONY ANYANWU* \\ Lincoln University \\ CHRISTOPHER GAN \\ Lincoln University \\ BAIDING HU \\ Lincoln University
}

\begin{abstract}
This paper analyses the relationship between bank credit and economic growth. We extend existing literature by treating separately the oil and non-oil sectors of 28 oildependent economies from 1990-2012. We employ panel cointegration and pooled mean group estimation techniques which are appropriate for drawing conclusions from dynamic heterogenous panels. The results of the panel cointegration test indicate that bank credit has no significant long-run relationship with non-oil GDP per capita. The results of the pooled mean group estimator reveal no significant long-run impact of bank credit on non-oil GDP per capita. Overall results suggest that banks do not yet provide adequate credit to stimulate non-oil economic growth. The policy implication of our findings is that the financial sector should be more involved in productive investment activities to promote inclusive growth.
\end{abstract}

Keywords: banks, oil-dependent, non-oil sector, credit, growth

JEL Classification: E02, 011, G21, E51

\section{Introduction}

Financial development promotes the growth of industries that are more reliant on external finance by overcoming financing constraints (Beck, Demirguc-Kunt and Maksimovic, 2005). Firms in resource-based economies use less external finance and a smaller proportion use bank loans, although the level of demand is similar to other countries, which indicates supply constraints (Beck, 2011). In light of this, financial sector development could assist the growth

\footnotetext{
* Corresponding Author: Dr. Amarachukwu Anthony Anyanwu. Lincoln University, Christchurch, New Zealand. Email: Amarachukwu.Anyanwu@lincolnuni.ac.nz

(C) 2018 Anthony Anyanwu, Christopher Gan and Baiding Hu. Licensed under the Creative Commons Attribution - Noncommercial 3.0 Licence (http://creativecommons.org/licenses/bync/3.0/. Available at http://rofea.org.
} 
of financially constrained firms in oil-dependent countries ${ }^{1}$ by improving access to finance (credit availability, cost of borrowing, etc.) which could lead to a meaningful contribution to economic diversification (captured through non-resource exports, non-oil growth and productivity). Economic diversification is of particular importance to mono-product economies, especially those dependent on oil, because of the negative effects of oil price volatility on macroeconomic indicators (e.g., investment, consumption, employment); government budget; and monetary policy.

The oil-sector is capital-intensive and does not contribute significantly to employment whereas the non-oil sector is labor-intensive, creates more jobs, and contributes immensely to economic development. The non-oil sector is the key driver of economic diversification and the performance of this sector is a yardstick to gauge the effectiveness of macroeconomic and financial sector policies. The non-oil private sector growth depends largely on the availability of private credit, but despite the great importance, bank credit to the private sector in oildependent countries is relatively low even though the banks are more liquid, better capitalized, and more profitable (Beck, 2011). Not surprisingly, the beneficial effect of private credit on economic growth is generally smaller in oil-exporting countries due to limited access to finance (Nili and Rastad, 2007; Barajas et al., 2013). Interestingly, the oildependent countries operate a dual economy (an existence of two distinct types of economic segments within an economy) and empirical studies do not properly capture the impact of finance on the non-oil sector.

Several empirical studies have estimated the effect of finance on economic growth in resource-rich countries; however, combining the oil and non-oil economies as one entity could be misleading because the oil sectors have better access to finance than the non-oil sector. Therefore, if disproportionate bank credits are lent to the resource sector and researchers misidentify that as the economy as a whole, then the effect of financial intermediation on growth may produce unreliable estimates. There is a need to isolate the economies and estimate the effects separately. For this reason, this study explores the differential impact of financial intermediation on economic growth.

\section{Literature Review}

Early examples of literature on financial intermediation and growth expound that countries with sustained economic growth tend to have developed financial sectors and that developed financial systems lead to higher economic growth (Patrick 1966; Goldsmith 1969; McKinnon 1973; Shaw 1973). Bencivenga and Smith (1991) argued that financial intermediaries reduce

\footnotetext{
${ }^{1}$ An oil-dependent country's average share of hydrocarbons in total fiscal revenue and/or total export proceeds is at least 25 percent of total GDP. Our sample study includes: Algeria, Angola, Equatorial Guinea, Gabon, Nigeria, Cameroon, Chad, Congo Republic, Dem. Rep. Congo, Bolivia, Mexico, Trinidad, Ecuador, Venezuela, Saudi Arabia, Qatar, Syria, Kuwait, Iran, Yemen, Bahrain, Oman, Azerbaijan, Kazakhstan, Papua New Guinea, Indonesia, Malaysia, and Vietnam.
} 


\section{ANYANWU, GAN, HU Financial Intermediation and Growth}

the amount of savings held in the form of unproductive liquid assets and prevent misallocations of capital due to liquidity needs. Levine (1997) asserts that financial systems influence growth by pooling savings, easing transaction costs, and strengthening information about possible investments. Ngai (2005) emphasized that bank credit to the private sector stimulates economic growth and it is an important source of financing for firms especially in countries where capital markets are underdeveloped. Recent studies have also shown that there is a positive link between financial development and economic growth (Bojanic 2012; Uddin et al. 2013; Greenwood et al. 2013; Beck et al. 2014; Pradhan et al. 2017)

Differences in financial development can be a source of comparative advantage in trade (Kletzer and Bardhan, 1987). Countries with identical technology and endowments with no economies of scale could face different production costs; that is moral hazard issues in the international credit market under sovereign risk and/or imperfect information in the domestic institutions may lead some countries or firms to face higher interest rates or credit rationing which could lead to disparity in competiveness. Rajan and Zangales (1998) posit that sectors which require more external finance grow faster in countries with higher financial development. The resources sector (i.e., oil and gas industries) has relatively lower external finance dependence which infers that financial development could help resource-rich countries to push their exports away from primary products and to greater economic diversification. Financial development exerts a large causal impact on the level of both exports and trade balance of manufactured goods (Beck, 2002). Thus, financial development is expected to lower the search costs, increase external finance, and encourage the production of goods with increasing returns to scale which could lead to the intensification and diversification of exports.

Gylfason and Zoega (2001) examined the effects of financial development on economic growth with cross-country OLS regression analysis across 85 countries from 1965 to 1998 and conclude that heavy dependence on natural resources hurts savings and investments and restrains the development of the financial system which hinders economic growth. Nili and Rastad (2007) assessed the effects of financial development on economic growth in 12 oilexporting countries from 1975-2000 using dynamic panel estimation technique (GMM) and find that the weakness of financial institutions is associated with the lackluster performance of the private sector. Beck (2011) tested the relationship between financial development and economic growth using a cross-country regression analysis and found that firms in resourcebased economies use a smaller proportion of bank loans even though the level of demand is similar to other countries, thus pointing to supply constraints. Barajas et al. (2013) used a dynamic panel estimation technique (GMM) for 150 countries over the period 1975-2005 and conclude that the beneficial effect of financial deepening on economic growth displays measurable heterogeneity; it is smaller in oil-exporting countries and in lower-income 
countries and the differences are driven by regulatory characteristics and differences in the ability to provide widespread access to financial services.

Hasanov and Huseynov (2013) scrutinized the impact of bank credits on non-oil tradable output in Azerbaijan based on the ARDL Bounds testing approach, Engle-Granger two-step methodology, and Johansen's approach. Results from the three approaches indicate that bank credits have a positive impact on non-oil tradable output both in the short and long-run. Cevik and Rahmati (2013) investigated the causal relationship between financial development and economic growth in Libya during the period 1970-2010. The VAR-based estimations show statistically insignificant effect on real non-hydrocarbon GDP per capita growth. Samargandi et al. (2014) explored the effect of financial development on economic growth in Saudi Arabia using the Autoregressive Distributed Lag (ARDL) bounds test technique and find that financial development has a positive impact on the growth of the non-oil sector in Saudi Arabia but its impact on total GDP growth is negative but insignificant. Mirzaei and Moore (2015) inspected the effect of bank performance on the non-oil industry sectors in Qatar over the period 2000-2006 and conclude that the quantity of finance does not seem to matter for industry growth but rather a competitive, efficient and stable banking system enhances financially dependent industries to grow faster. Badeeb et al. (2016) estimated the financegrowth nexus in Malaysia and find no direct effect of financial development on economic growth, however, there are direct and positive effects on the level of investment.

This research study contributes to the existing literature by appraising the impact of financial intermediation on the emerging non-oil sector. The few related empirical studies have markedly different results and all of them used time-series approach; as such, inference may be unreliable compared to panel data methods. In contrast, our techniques avoid these problems by combining 23 time observations with 28 cross-sections resulting in a sample of 539 observations. This produces great improvements in the reliability of statistical inference while allowing for cross-country heterogeneity. We bypass the limitations of standard panel cointegration methods by allowing for cross-country dependence.

\section{Data and Methodology}

The annual data are obtained from the World Bank World Development Indicator (WDI) and encompasses the 1990-2012 period for a panel of 28 oil-dependent countries. It includes all the countries for which data were available though some variables are limited to a much smaller group. Natural resource dependence is as high as $90 \%$ in Algeria, Angola, Azerbaijan, Congo Rep., Nigeria, Kuwait, Equatorial Guinea, and Venezuela and as low as $25 \%$ in Malaysia, Indonesia, and Vietnam. Norway is excluded because it is a highly developed country. Russia is excluded because it is borderline on most developed-country metrics. Due to missing data issues, Iraq and Libya are excluded. 


\section{ANYANWU, GAN, HU Financial Intermediation and Growth}

GDP Per Capita Growth $\rightarrow$ This study follows the convention in the literature by using real per capita GDP as an indicator of growth. Thereafter, we excluded the hydrocarbon sector and derived the non-hydrocarbon GDP per capita.

Bank Credit $\rightarrow$ This measure indicates the extent to which funds are channeled into the private sector by the domestic banks. One of the most critical factors when investigating the relationship between financial development and economic growth is how to attain a reasonable measure of financial development. Bank credit is better than other measures of financial development because it is more directly linked to investment and growth, that is, credit granted to the private sector by the banks. Moreover, we are concerned with financial intermediation; bank credit to the private sector captures financial intermediation and the quantitative development of the banking sector.

Government Consumption $\rightarrow$ This variable is measured by the share of government consumption as a percentage of GDP. It excludes expenditure on capital, transfers and debt servicing. This indicator is particularly important in oil-dependent economies because of the high level of fiscal leakage coupled with lack of transparency and accountability (Ades and Di Tella, 1999).

Trade Openness $\rightarrow$ The Openness Index is calculated as the ratio of country's total trade, the sum of exports plus imports, to the country's gross domestic product. This could possibly facilitate economic growth by increasing domestic firms' markets and by allowing them to acquire inputs at competitive prices (Shan et al., 2006).

Price of Crude Oil $\rightarrow$ We use annual average Brent Crude oil spot price as a major benchmark price for purchases of oil worldwide. Using the oil price index as an independent variable allows us to measure the impact of world oil price fluctuation on the non-oil sector. We deflate this variable by the consumer price index (CPI) to obtain the real crude oil price.

\subsection{Model Specification}

The basic empirical model we postulate for modelling financial intermediation and economic growth, which are denoted by $F D_{i t}$ and $Y_{i t}$ respectively, is the following function.

$$
\ln \left(Y_{i t}\right)=u_{i}+\beta_{i} \ln \left(F D_{i t}\right)+e_{i t}
$$

where the index $\mathrm{i}=1, \ldots, N$ denotes countries, $\mathrm{t}=1,2, \ldots ., T$ denotes time.

The estimation approach is presented under sub-themes: panel unit root test, panel cointegration test, and pooled mean group estimator. 


\subsection{Panel Unit Root Test}

This study employs a Fisher-type test to check whether the variables are stationary or not. The advantage is that it does not require a balanced panel.

Choi (2001) considers the following model using the properties of the Fisher test:

$$
y_{i t}=d_{i t}+x_{i t}
$$

where $\mathrm{i}=1,2 \ldots N$ represents the cross-sectional units $\mathrm{t}=1,2, \ldots, T$ represents the time period. Moreover, the observed data comprises two components, namely a non-stochastic component $\left(\mathrm{d}_{\mathrm{it}}\right)$ and a stochastic component $\left(\mathrm{X}_{\mathrm{it}}\right): d_{i t}=\beta_{i o}+\beta_{i 1} t+\cdots+\beta_{i m i} t^{m} i$ and $X_{i t}=$ $p_{i} x_{1(t-1)}+u_{i t}$, where $u_{i t}$ is integrated of zero and may be heteroskedastic. The null hypothesis is given as: $H_{o}: p_{i}-1$ for all $i$. Which implies the presence of a unit root. The alternative hypothesis is: $H_{a}:\left|p_{i}\right|<1$ for at least one $i$ for finite $N$ or $H_{a}:\left|p_{i}\right|<1$ for some $i$ 's for infinite $N$. Next, let $G_{i T i}$ be a one-sided unit test statistics (ADF and PP in our study) for i-th group in Eq. (2), based on the following assumptions:

i) Under the null, as $T_{i} \rightarrow \infty, G_{i T i} \rightarrow G_{i}$, (Gi $G_{i}$ being a non-degenerate random variable)

ii) $u_{i t}$ is independent of $u_{j s}$ for all $t$ and $s$ when $\mathrm{i} \neq \mathrm{j}$

iii) $\frac{N k}{N} \rightarrow \mathrm{K}$ as $\mathrm{N} \rightarrow \infty$, (K being a fixed constant)

Then the asymptotic p-value for the $G_{i T i}$ under assumption (i) is defined as $p_{i}=F\left(G_{i T i}\right)$ where $\mathrm{F}($.$) is the distribution function of G_{i}$. The proposed inverse chi-squared Fisher type panel unit root test statistics has the following form:

$$
P=-2 \sum_{i=1}^{N} \log p_{i}
$$

Equation (3) combines the $p$-values from the unit root tests for each cross sectional unit $i$ to test for unit root in the panel. Under the null hypothesis of unit root, $P$ is distributed as $X^{2}(2 N)$ as $T_{i} \rightarrow \infty$ for all $N$.

\subsection{Panel Cointegration Test}

We use the four panel cointegration tests of Westerlund (2007) which have good smallsample properties and high power relative to the popular residual-based panel cointegration tests (e.g. Pedroni, 2004). Second, the time series are allowed to be of unequal length. The four panel cointegration test of Westerlund (2007) tests is designed to test the null hypothesis of no cointegration by testing whether the error correction term in a conditional error 


\section{ANYANWU, GAN, HU Financial Intermediation and Growth}

correction model is equal to zero. If the null hypothesis of no error correction is rejected, then the null hypothesis of no cointegration is also rejected. Westerlund (2007) considers the following error correction model where all variables in levels are assumed to be integrated of order 1;

$$
\Delta Y_{i t}=\delta_{i}^{\prime} d_{t}+\alpha_{i}\left(Y_{i t-1}-\beta_{i}^{\prime} x_{i t-1}\right)+\sum_{j=1}^{p i} \alpha_{i j} \Delta Y_{i t-j}+\sum_{j=0}^{p i} Y_{i j} \Delta x_{i t-j}+e_{i t}
$$

where $d_{t}=(1, \mathrm{t})^{\prime}$ holds the deterministic components, $\delta_{i}^{\prime}=\left(\delta_{1 i}, \delta_{2 i}\right)^{\prime}$ are the associated vector of parameters. In order to allow for the estimation of the error correction parameter $\alpha_{i}$ by least squares;

$$
\Delta Y_{i t}=\delta_{i}^{\prime} d_{t}+\alpha_{i} Y_{i t-1}-\lambda_{i}^{\prime} x_{i t-1}+\sum_{j=1}^{p i} \alpha_{i j} \Delta Y_{i t-j}+\sum_{j=0}^{p i} Y_{i j} \Delta x_{i t-j}+e_{i t}
$$

Here the parameter $\alpha_{i}$ provides an estimate of the speed of error correction towards the long run equilibrium. Next, it is possible to construct a valid test of $H_{o}$ versus $H_{a}$ that is asymptotically similar and whose distribution is free of nuisance parameters. Westerlund (2007) proposes four tests based on the least squares estimates of $\alpha_{i}$ and its $t$-ratio for each individual $i$. The first two are called 'group mean' and given as:

$$
\mathrm{G}_{\mathrm{t}}=\frac{1}{\mathrm{~N}} \sum_{\mathrm{i}=1}^{\mathrm{m}} \frac{\widehat{\alpha}_{\mathrm{i}}}{\operatorname{SE}\left(\widehat{\alpha}_{\mathrm{i}}\right)} \text { and } \quad \mathrm{G}_{\alpha}=\frac{1}{\mathrm{~N}} \sum_{\mathrm{i}=1}^{\mathrm{m}} \frac{\mathrm{T} \widehat{\alpha}_{\mathrm{i}}}{\widehat{\alpha}_{\mathrm{i}}(1)}
$$

where SE $\left(\hat{\alpha}_{i}\right)$ is the standard error of $\hat{\alpha}_{i} . G_{t}$ and $G_{\alpha}$ test the null of $H_{o}: \alpha_{i}=0$ for all $i$ versus the alternative of $H_{a}: \alpha_{i}<0$ for at least one $i$. In other words, the $G_{t}$ and $G_{\alpha}$ test the null hypothesis of no cointegration for all cross-sectional units against the alternative that there is cointegration of at least one cross-sectional unit. The rejection of the null should therefore be taken as evidence of cointegration of at least one of the cross-sectional units. The other two tests are called 'panel test' and given as follows: $P_{t}=\frac{\widehat{\alpha}}{\operatorname{SE}(\widehat{\alpha})}$ and $P_{\alpha}=T \hat{\alpha}$

The $P_{t}$ and $P_{\alpha}$ test $H_{o}: \alpha_{i}=0$ for all $\mathrm{i}$ versus the alternative of $H_{a}: \alpha_{i}<0$ for all i. In other words, $P_{t}$ and $P_{\alpha}$ test statistics pool information over all the cross-sectional units to test the null of no cointegration for all cross-sectional units against the alternative of cointegration for all cross-sectional units. The rejection of the null should therefore be taken as evidence of cointegration for the panel as a whole. With a small dataset, the results of the tests may be sensitive to the specific choice of lag and lead lengths which means if there is a crosssectional dependence over the units, the group mean and panel statistics are no longer valid (Westerlund, 2007). Hence, to avoid over-parameterization and the loss of predictive power, robust critical values are obtained through bootstrapping. 


\subsection{Pooled Mean-Group Estimator}

The panel cointegration test of Westerlund (2007) tests the existence of long-run relationship but does not show the short-run and long-run estimates. We apply the pooled mean-group (PMG) estimator of Pesaran et al. (1999). There are several gains in using the PMG estimator over other dynamic panel data estimators i.e. panel dynamic OLS (DOLS) of Pedroni (2001); panel fully modified OLS (FMOLS) of Pedroni (2000); GMM of Arellano and Bond (1991) and Blundell-Bond (1998). DOLS and FMOLS require pre-testing for unit roots in the variables as well as pre-testing for cointegration between integrated regressors. The stationary variables that do not appear to be part of the estimated cointegrating vector are usually eliminated (Pedroni, 2000, 2001). For example, if any of the variables, like bank credit, and government consumption are stationary, I (0); and other variables such as oil price, and nonoil GDP per capita are non-stationary, 1(1); some variables will be dropped in the DOLS/FMOLS in order to keep the same order of integration. The generalized methods of moment (GMM) estimator addresses potential misspecification and obtains consistent estimates in the presence of endogenous regressors. However, Pesaran et al. (1999) argue that the GMM estimation procedure for the dynamic panel data model can produce inconsistent and misleading coefficients of the long-run coefficients since GMM captures mainly the short-run dynamics. Thus, it is not clear whether the estimated panel models represent a longrun equilibrium relationship or a spurious one (Christopoulos and Tsionas, 2004). Therefore, we ignore these dynamic panel data estimators.

The PMG estimator is consistent even if the variables of interest are integrated or stationary, endogenous or deterministic (Pesaran et al., 1999). Therefore, checking for the presence of unit roots in the panel variables is unnecessary. The PMG estimator assumes cross-sectional independence of the regression residuals. The inclusion of sufficient lags of the right-hand side regressors ensures the regression errors are serially uncorrelated and the explanatory variables are exogenous and thus provide consistent and efficient parameters of interest. There are reasons to believe that the long-run equilibrium relationship amongst the variables of interest are identical across the oil-dependent economies (i.e. the presence of a common factor: oil prices), while the short-run dynamics are heterogeneous. Thus, the PMG estimator is likely to capture the true nature of the data. However, making a choice between DFE, MG and PMG estimators can be tested with the Hausman test; the Hausman test calculates the difference between the DFE, MG and PMG estimators, then compares the difference to critical values from the chi-squared distribution. Under the null hypothesis of cross-section parameter homogeneity in the long-run, one would expect the difference to be small. Therefore, if the p-value is $>0.05$ ) (i.e. insignificant, use PMG estimates).

Let us assume that the long-run growth relationship is given by: 
ANYANWU, GAN, HU Financial Intermediation and Growth

$$
\begin{aligned}
\mathrm{Y}_{\mathrm{it}} & =\theta_{0 \mathrm{i}}+\theta_{1 \mathrm{i}} \text { BANKCREDIT }_{\mathrm{it}}+\theta_{2 \mathrm{i}} \text { GOVERNMENTSIZE }_{\mathrm{it}}+ \\
& +\theta_{3 \mathrm{i}} \text { TRADEOPENNESS }_{\mathrm{it}}+\theta_{4 \mathrm{i}} \text { OILPRICE }_{\mathrm{it}}+\alpha_{1 \mathrm{i}}+\mathrm{u}_{\mathrm{it}}
\end{aligned}
$$

Assume the variables in equation (6) are I (1) and cointegrated. This implies $u_{i t}$ is an I (0) process for all $i$ and is independently distributed across $t$. They are also assumed to be distributed independently of the regressors. Suppose our maximum lag of every variable is one, the autoregressive distributed lag, $\operatorname{ARDL}(1,1,1,1,1)$, model becomes:

$$
\begin{aligned}
\mathrm{Y}_{\mathrm{it}} & =\mathrm{u}_{\mathrm{it}}+\delta_{10 \mathrm{i}} \text { BANKCREDIT }_{\mathrm{it}}+\delta_{11 \mathrm{i}} \text { BANKCREDIT }_{\mathrm{it}-1}+\delta_{20 \mathrm{i}} \text { GOVERNMENTSIZE }_{\mathrm{it}}+ \\
& +\delta_{21 \mathrm{i}} \text { GOVERNMENTSIZE }_{\mathrm{it}-1}+\delta_{30 \mathrm{i}} \text { TRADEOPENNESS }_{\mathrm{it}}+\delta_{31 \mathrm{i}} \text { TRADEOPENNESS }_{\mathrm{it}-1} \\
& +\delta_{40 \mathrm{i}} \text { OILPRICE }_{\mathrm{it}}+\delta_{41 \mathrm{i}} \text { OILPRICE }_{\mathrm{it}-1}+\beta_{1 \mathrm{i}} \mathrm{t}+\lambda_{\mathrm{i}} \mathrm{Y}_{\mathrm{it}}+\mathrm{e}_{\mathrm{it}}
\end{aligned}
$$

The error correction equilibrium representation is derived as:

$$
\begin{aligned}
\Delta \mathrm{Y}_{\mathrm{it}} & =\phi_{\mathrm{i}}\left(\mathrm{Y}_{\mathrm{it}-1}-\theta_{0 \mathrm{i}}-\theta_{1 \mathrm{i}} \text { BANKCREDIT }_{\mathrm{it}}-\theta_{2 \mathrm{i}} \text { GOVERNMENT SIZE }_{\mathrm{it}}\right. \\
& \left.-\theta_{31} \text { TRADEOPENNESS }_{\mathrm{it}}-\theta_{4 \mathrm{i}} \text { OILPRICE }_{\mathrm{it}}-\alpha_{1 \mathrm{i}} \mathrm{t}\right)-\Delta \delta_{11 \mathrm{i}} \text { BANKCREDIT }_{\mathrm{it}-1} \\
& -\Delta \delta_{21 \mathrm{i}} \text { GOVERNMENTSIZE }_{\mathrm{it}-1}-\Delta \delta_{31 \mathrm{i}} \text { TRADEOPENNESS }_{\mathrm{it}-1}-\Delta \delta_{41 \mathrm{i}} \text { OILPRICE }_{\mathrm{it}-1}+\mathrm{e}_{\mathrm{it}}
\end{aligned}
$$

where

$\theta_{0 \mathrm{i}}=\frac{\mathrm{u}_{\mathrm{it}}}{1-\lambda_{\mathrm{i}}}, \theta_{1 \mathrm{i}}=\frac{\delta_{10 \mathrm{i}+\delta_{11 \mathrm{i}}}}{1-\lambda_{\mathrm{i}}}, \theta_{2 \mathrm{i}}=\frac{\delta_{20 \mathrm{i}+\delta_{21 \mathrm{i}}}}{1-\lambda_{\mathrm{i}}}, \theta_{3 \mathrm{i}}=\frac{\delta_{30 \mathrm{i}+\delta_{31 \mathrm{i}}}}{1-\lambda_{\mathrm{i}}}, \theta_{4 \mathrm{i}}=\frac{\delta_{40 \mathrm{i}+\delta_{41 \mathrm{i}}}}{1-\lambda_{\mathrm{i}}}, \phi_{\mathrm{i}}-1-\lambda_{\mathrm{i}}$

The mean group (MG) and dynamic fixed effect (DFE) estimation results will be reported to facilitate comparison.

\section{Empirical Results}

\subsection{Panel Unit Roots}

Table (1) reports the results of the unit root tests, which suggest that one of the variables under consideration (i.e. non-hydrocarbon GDP) is stationary of order I(0); while bank credit, government expenditure, trade openness, and the price of crude oil are integrated of order I(1). The results show all variables are stationary at first difference.

\subsection{Panel Cointegration}

The Westerlund panel cointegration test identifies the presence of long-run relationships among the integrated variables. The lag-length is crucial since excessively short lags may fail 
Review of Economic Analysis 10 (2018) 267-284

Table 1: Panel Unit Root Test

\begin{tabular}{|l||c|c|c|c|}
\hline \multicolumn{1}{|c|}{} & \multicolumn{4}{c|}{ Fisher -type test } \\
\cline { 2 - 5 } & \multicolumn{3}{|c|}{ Level } & \multicolumn{2}{c|}{$1^{\text {st }}$ difference } \\
\hline Variables & Test Values & P-values & Test Values & P-values \\
\hline \hline Non-hydo. GDP & -4.8361 & 0.0001 & -18.4309 & 0.000 \\
\hline Bank Credit & -0.6069 & 0.2719 & -14.5823 & 0.000 \\
\hline Govt. Consumption & -1.3236 & 0.1929 & -16.4452 & 0.000 \\
\hline Trade Openness & -1.4412 & 0.1747 & -19.0764 & 0.000 \\
\hline Price of Crude Oil & 1.7918 & 0.1634 & -21.4115 & 0.000 \\
\hline
\end{tabular}

Note: all unit roots are implemented with a constant and trend and take the unit root as the null hypothesis. The lags are chosen according to the Akaike criterion. Source: Author's calculations.

to capture the system's dynamics, or lead to omitted variables, or bias the coefficients, and likely to produce serially correlated errors. Meanwhile too long a lag leads to a rapid loss of degrees of freedom and to over-parameterization (Kireyev, 2000). To choose an optimal lag and lead length for each series, we use the AIC criterion while the Bartlett Kernel window width is set to $4 /(\mathrm{T} / 100)^{2 / 9}=3$. All variables are stationary at first difference and integrated of order 1(1), we apply the panel cointegration test using the first-difference variables.

The result of the cointegration test (Table 2) shows that the $G_{a}$ and $P_{a}$ test statistics accept the null of no cointegration for non-hydrocarbon GDP per capita which suggests there is little evidence of cointegration. However, only $P_{t}$ test statistics accepts the null of no cointegration for GDP per capita which suggest there is some evidence of cointegration.

However, panel data models tend to exhibit cross-sectional dependence in the errors which could arise due to the presence of common shocks and unobserved components that become part of the error (Pesaran, 2004). The reason may be as a result of the increasingly economic and financial integration of countries, and particularly in our research study, the common shock of oil price fluctuations which affects government consumption and bank credit. We use the Pesaran (2004) CD test on the residuals of the FE specification. The CD test statistics is normally distributed under the null hypothesis of no cross-sectional dependence. The result strongly indicates the presence of a common factor affecting the cross-sectional units ${ }^{2}$. We

2 The Pesaran's test of cross sectional independence $=40.368, \operatorname{Pr}=0.0000$. Average absolute value of the offdiagonal elements $=0.292$. Hence, there is evidence to suggest the presence of cross-sectional dependence. 
ANYANWU, GAN, HU Financial Intermediation and Growth

Table 2: Westerlund Panel Cointegration Test

\begin{tabular}{|l||c|c|c|c|c|c|}
\hline \multicolumn{1}{|c||}{} & \multicolumn{2}{|c|}{ Non-hydrocarbon GDP Per Capita } & \multicolumn{3}{c|}{ GDP Per Capita } \\
\hline Test & Values & Z-values & P-Values & Values & Z-values & P-Values \\
\hline \hline $\mathrm{Gt}$ & -4.058 & -11.212 & 0.000 & -3.974 & -10.658 & 0.000 \\
\hline $\mathrm{Ga}$ & -13.32 & -1.132 & 0.129 & -13.415 & -1.207 & 0.000 \\
\hline $\mathrm{Pt}$ & -17.383 & -7.225 & 0.000 & -16.991 & -6.767 & 0.114 \\
\hline $\mathrm{Pa}$ & -10.339 & -1.227 & 0.110 & -16.597 & -6.771 & 0.000 \\
\hline
\end{tabular}

Note: the Westerlund (2007) tests take no cointegration as the null. The test regression is fitted with a constant, and a range of lags (1 2) and leads (1 2). Source: Author's calculations.

Table 3: Westerlund Panel Cointegration Test, Bootstrapped

\begin{tabular}{||l||c|c|c|c|c|c|c|c|}
\hline \multicolumn{1}{|c||}{} & \multicolumn{3}{c|}{ Non-hydrocarbon GDP Per Capita } & \multicolumn{4}{c|}{ GDP Per Capita } \\
\cline { 2 - 9 } Test & Values & Z-values & P-values & $\begin{array}{c}\text { Robust } \\
\text { P-Values }\end{array}$ & Values & Z-values & P-values & $\begin{array}{c}\text { Robust } \\
\text { P-Values }\end{array}$ \\
\hline \hline $\mathrm{Gt}$ & -2.518 & -0.985 & 0.162 & 0.136 & -2.101 & -0.736 & 0.048 & 0.027 \\
\hline $\mathrm{Ga}$ & -7.188 & 3.753 & 1.000 & 0.511 & -7.812 & -2.837 & 0.038 & 0.021 \\
\hline $\mathrm{Pt}$ & -11.02 & 0.179 & 0.571 & 0.351 & -10.263 & -9.462 & 0.046 & 0.034 \\
\hline $\mathrm{Pa}$ & -6.283 & 2.287 & 0.889 & 0.385 & -8.173 & -1.287 & 0.062 & 0.056 \\
\hline
\end{tabular}

Note: Because the Akaike optimal lag and lead search are time-consuming when combined with bootstrapping, we held the short-term dynamics fixed. Source: Author's calculations

bootstrapped robust critical values for the test statistics i.e. $p$-values, which provide stronger evidence (see Table 3). Bootstrapping corrects critical values in tests; it reduces the difference between the true and nominal rejection probabilities. Thus, for GDP per capita, the no cointegration null is rejected for $G_{i}$ at the $5 \%$ level and for $P_{i}$ at the $10 \%$ level (i.e. when $P_{i}$ is restricted to be homogenous) which suggests that the whole panel is cointegrated. However, $G_{i}$ test statistics accepts the null of no cointegration for non-hydrocarbon GDP per capita and $P_{i}$ test statistics accepts the null of no cointegration for the whole sample. This shows bank credit has no long-run relationship or at best a weak relationship with non-oil GDP per capita. 


\subsection{Pooled Mean Group}

We address endogeneity concerns using lags of the regressors and dependent variables to minimize bias and to ensure the regression residuals are serially uncorrelated. The existence of a long-run relationship (dynamic stability) requires that the coefficient on the errorcorrection term be negative and not lower than -2 (Loayza. and Ranciere, 2006). The PMG error-correction term coefficient falls within the dynamically stable range. The long-run parameters should be the same across countries; this is confirmed by the Hausman test which accepts the null hypothesis of the homogeneity restriction on the regressors in the long-run.

The results reported in Table 4 and 5 indicate that a $1 \%$ increase of bank credit increases GDP per capita by 0.06 percent, whereas, $1 \%$ increase of bank credit to the non-oil sector decreases non-oil GDP per capita by 0.01 percent, though statistically insignificant. There is a weak link between bank credit and the non-oil economic growth. Banks do not yet provide adequate credit to stimulate non-oil economic growth.

The results show that $1 \%$ increase in government consumption increases non-oil GDP per capita by 0.14 percent; however, this decreases GDP per capita by 0.15 percent. Government consumption boosts non-oil economic activities; but overall, it has a depressing effect on economic growth. This is expected given the high level of fiscal leakage in oil-dependent economies which do not contribute to economic growth but boost non-oil economic growth through the demand and services provided by private businesses.

A \$1 increase in the world price of crude oil increases non-oil GDP per capita by 0.2 percent, significantly more than the 0.07 percent for GDP per capita. This is not surprising given that the non-oil sector is financially constrained; therefore, the injection of funds through spill-over effects of increased oil revenues has greater effect on growth.

The effect of trade openness on non-oil GDP per capita is statistically insignificant. The evidence for growth enhancement through trade openness displays mixed effects in the literature, however, the beneficial effects of trade openness seem to increase as economies develop and most of the economies in our sample study are in the infant stage of economic development. Moreover, natural resource abundance reduces openness through weakening of the manufacturing sector which retards integration into the world economy.

Our results show that non-oil economic growth is strongly associated with movements in oil prices and government consumption. Some empirical studies lend support to that (Kireyez 1998; Treichel 1999; Baldini 2005; Kumah and Matovu 2005; Hussain et al. 2008; Agnani and Iza 2011; Cevik and Rahmati 2013)

There are possible reasons for the weak link between bank credit and the growth of the non-oil GDP. First, the financial system is still in the rudimentary stage or at best, transition 
ANYANWU, GAN, HU Financial Intermediation and Growth

Table 4: Non-Oil GDP $=f($ Bank Credit, Govt. Consumption, Trade Openness, Oil Price $)$

\begin{tabular}{|c|c|c|c|c|c|c|c|c|}
\hline \multirow[b]{2}{*}{ Variable } & \multicolumn{2}{|c|}{$\begin{array}{l}\text { Pooled Mean } \\
\text { Group }\end{array}$} & \multicolumn{2}{|c|}{ Mean Group } & \multicolumn{2}{|c|}{ Hausman Test } & \multicolumn{2}{|c|}{$\begin{array}{c}\text { Dynamic Fixed } \\
\text { Effect }\end{array}$} \\
\hline & Coef. & $\begin{array}{l}\text { Std. } \\
\text { Error }\end{array}$ & Coef. & $\begin{array}{l}\text { Std. } \\
\text { Error }\end{array}$ & H-test & $\begin{array}{l}\mathrm{P}- \\
\text { value }\end{array}$ & Coef. & $\begin{array}{l}\text { Std. } \\
\text { Error }\end{array}$ \\
\hline \multicolumn{9}{|c|}{ Long-Run Coefficients } \\
\hline Bank Credit & -0.014 & 0.008 & 0.228 & 0.129 & & & 0.024 & 0.019 \\
\hline $\begin{array}{l}\text { Government } \\
\text { Consumption }\end{array}$ & $0.149 * * *$ & 0.047 & 0.828 & 0.636 & & & 0.055 & 0.102 \\
\hline Trade Openness & 0.003 & 0.005 & -0.138 & 0.128 & & & -0.013 & 0.012 \\
\hline Price of Crude Oil & $0.222 * * *$ & 0.033 & 0.713 & 0.894 & & & 0.168 & 0.129 \\
\hline & & & \multicolumn{2}{|c|}{ Hausman Test ${ }^{1}$} & 2.57 & 0.636 & & \\
\hline & & & \multicolumn{2}{|c|}{ Hausman Test $^{2}$} & 2.21 & 0.595 & & \\
\hline $\begin{array}{l}\text { Error Correction } \\
\text { Coefficient }\end{array}$ & $-0.106^{* * *}$ & 0.022 & $-0.531 * * *$ & 0.078 & & & $0.116 * * *$ & 0.016 \\
\hline$\Delta$ Bank Credit & 0.239 & 0.141 & 0.152 & 0.108 & & & $0.009 * *$ & 0.018 \\
\hline $\begin{array}{l}\Delta \text { Government } \\
\text { Consumption }\end{array}$ & 0.135 & 0.077 & -0.008 & 0.096 & & & $0.079 * *$ & 0.016 \\
\hline$\Delta$ Trade Openness & 0.003 & 0.016 & -0.012 & 0.023 & & & $0.007 *$ & 0.002 \\
\hline$\Delta$ Price of Crude Oil & $-0.192 * *$ & 0.062 & -0.059 & 0.119 & & & $-0.115^{*}$ & 0.031 \\
\hline Intercept & $3.562 * *$ & 1.486 & $6.824 *$ & 3.679 & & & $-3.424 *$ & 0.894 \\
\hline Country & 28 & & 28 & & & & 28 & \\
\hline Observations & 539 & & 539 & & & & 539 & \\
\hline
\end{tabular}

Note: $* * *$, and $* * *$ indicate significance at $10 \%, 5 \%$ and $1 \%$, respectively. Estimations are estimated using (xtpmg) routine in Stata. Pooled mean group, mean group, and dynamic fixed effects all control for country and time effects. The first panel (LR) shows the long-run effects. The second panel reports both short-run effects (SR) and the speed of adjustment (ec). The Hausman test indicates that PMG is a more consistent and efficient estimator than MG and DFE. The lag structure is ARDL $(1,1,1,1,1)$ and the order of variables is non-hydrocarbon GDP per capita growth, bank credit, government consumption, trade openness, and oil price. All variables are in constant 2005 U.S dollars. PMG is a more efficient estimator than MG under the null hypothesis ${ }^{1}$. PMG is a more efficient estimator than DFE under the null hypothesis ${ }^{2}$. Annual data 1990-2012. Source: Author's calculation

phase, and has only made modest attempt to lend to the non-oil sector in the last decade. Financial intermediation needs to reach a certain level of development before it could promote economic growth (Berthelemy and Varoudakis 1996; Cherif and Gazdar 2015).

Second, the weak institutional environment somewhat explains the reluctance of banks to lend to the non-oil related businesses as banks avoid risks associated with eventual difficulties in loan recovery. 
Review of Economic Analysis 10 (2018) 267-284

Table 5: GDP $=f($ Bank Credit, Govt. Consumption, Trade Openness, Oil Price $)$

\begin{tabular}{|l|c|c|}
\hline & \multicolumn{2}{|c|}{ Pooled Mean Group } \\
\hline Variable & Coef. & Std. Error \\
\hline Long-Run Coefficients & $0.0567^{* * *}$ & 0.014 \\
\hline Bank Credit & $-0.158^{* *}$ & 0.047 \\
\hline Government Consumption & -0.075 & 0.005 \\
\hline Trade Openness & $0.071^{* * *}$ & 0.033 \\
\hline Price of Crude Oil & & 0.025 \\
\hline Error Correction Coefficient & 0.631 & 0.054 \\
\hline Bank Credit & 0.132 & 0.113 \\
\hline Government Consumption & 0.057 & 0.205 \\
\hline Trade Openness & 0.178 & 0.175 \\
\hline Price of Crude Oil & 3.563 & 2.247 \\
\hline Intercept & 28 & \\
\cline { 1 - 2 } Country & 539 & \\
\hline Observations & \multicolumn{2}{|l}{} \\
\hline
\end{tabular}

Note: $* *$ and $* * *$ indicate significance at $5 \%$ and $1 \%$, respectively

Source: Author's calculations

Third, the returns from financial development depends on the allocation of funds to productive investment projects but due to the improper allocation of resources, the interaction is not strong in the non-oil sector.

Fourth, the low level of bank credit reflects lack of competition (given the high profitability of banks in resource-rich economies) which allows banks to keep their credit levels low.

The weak link between real economic activities and bank credit goes a long way in explaining why bank credit does not result in non-oil economic growth. Fixing this link is essential for a more inclusive and sustainable economy.

\section{Conclusion}

This study examines the impact of bank credit in the emerging non-oil sectors of oildependent economies using panel cointegration and pooled mean group estimation techniques. The panel cointegration results indicate that there is no statistically significant long-run relationship between bank credit and non-oil GDP per capita. The pooled mean group estimator shows that bank credit has no significant effect on non-oil GDP per capita. The good performance of our regressions and the stability of our results support the appropriateness of the econometric methods we employed. These results have important development policy implications. 


\section{ANYANWU, GAN, HU Financial Intermediation and Growth}

Banks dominate the financial system and the non-bank financial institutions do not play an active role; as a result, options to access finance for the non-oil sector tend to be more limited, less efficient and more expensive. The lack of access to finance is a key barrier to private sector growth. This calls for efforts in oil-dependent economies to deepen and broaden financial systems.

However, developing a growth-enhancing financial system requires a set of policy measures such as protecting creditor rights, strengthening judicial enforcement, restructuring the insolvency system, maintaining high standards of corporate governance, improving competition in the banking sector, and improving credit information gathering and sharing system. These will strengthen the financial infrastructure and promote access to financial services.

Nonetheless, strengthening the financial system infrastructure is not enough. A considerable share of the non-oil activities is driven by the public sector but this seems to be running out of steam as government finances become tighter amidst falling oil prices. There is a need to adopt structural reforms to foster non-oil private sector growth independent from government spending. Such policies, incentives, and programs should facilitate businessfriendly climate, competition, and foreign investment in a wide range of activities.

\section{References:}

Agnani, Betty, and Amaia Iza (2011), Growth in an Oil Abundant Economy: The Case of Venezuela, Journal of Applied Economics, 14 (1), 61-79.

Arellano, Manuel, and Stephen Bond (1991), Some Tests of Specification for Panel Data: Monte Carlo Evidence and an Application to Employment Equations, Review of Economic Studies 58, 277-297.

Ades, Alberto, and Rafael Di Tella (1999), Rents, Competition, and Corruption, American Economic Review 89, 982-993.

Badeeb, Ramez and Lean, Hooi Hooi and Smyth, Russell (2016), Oil Curse and Finance-

Growth Nexus in Malaysia: The Role of Investment. Energy Economics, 57(C), 154-165.

Blundell, Richard, and Stephen Bond (1998), Initial Conditions and Moment Restrictions in Dynamic Panel-Data Models. Journal of Econometrics 87, 115-143.

Barajas, Aldofo and Ralph, Chami and Seyed, Reza Yousefi (2013), The Finance and Growth Nexus Re-examined: Do All Countries Benefit Equally? IMF Working Paper No. 13-130. International Monetary Fund.

Bencivenga, Valerie, and Bruce Smith (1991), Financial Intermediation and Endogenous Growth, Review of Economics Studies 58(2), 195-209.

Baldini, Alfredo (2005), Fiscal Policy and Business Cycles in an Oil-Producing Economy: The Case of Venezuela, IMF Working Paper 05/237 (Washington: International Monetary Fund) 
Berthelemy, Jean Claude, and Aristomene Varoudakis (1996), Financial Development, Policy and Economic Growth In N. Hermes, R. Lensink (Eds) Financial Development and Economic Growth: Theory and Experiences from Developing Countries, London, Routledge, 53-66.

Beck, Thorsten (2002), Financial Development and International Trade: Is There a Link? Journal of International Economics 57(1), 107-131.

Beck, Thorsten, Degryse, Hans and Kneer, Christiane (2014), Is More Finance Better? Disentangling Intermediation and Size Effects of Financial Systems. Journal of Financial Stability, 10(C), 50-64.

Beck, Thorsten (2011), Finance and Oil: Is There a Resource Curse in Financial Development? Tilburg, The Netherlands: Tilburg University.

Beck, Thorsten, Demirgüç-Kunt, Asli, and Maksimovic Vojislav (2005), Financial and Legal Constraints to Firm Growth: Does Firm Size Matter. Journal of Finance 60(1), 137-177.

Bojanic, Antonio (2012), The impact of Financial Development and Trade on the Economic Growth of Bolivia. Journal of Applied Economics, 15(1), 51-70.

Cevik, Serhan, and Mohammad Rahmati (2013), Searching for the Finance-Growth Nexus in Libya, IMF Working Papers 13/92, International Monetary Fund.

Choi, In (2001), Unit Root Tests for Panel Data, Journal of International Money and Finance 20, 249-272.

Cherif, Monther, and Kaothar Gazdar (2015), Institutions and the Finance-Growth Nexus, Empirical Evidence from MENA Countries, Borsa Istanbul Review 15(3), 137-160.

Christopoulos, Dimitris, and Efthymios Tsionas (2004), Financial Development and Economic Growth: Evidence from Panel Unit Root and Cointegration Tests, Journal of Development Economics 73, 55-74.

Demetriades, Panicos, and Gregory James (2011), Finance and Growth in Africa: The Broken Link. Economics Letters 113(3), 263-265.

Gylfason, Thorvaldur, and Gylfi Zoega (2001), Natural Resources and Economic Growth: The Role of Investment, C.E.P.R. Discussion Papers 2743, C.E.P.R. Discussion Papers.

Goldsmith, Raymond (1969), Financial Structure and Development. New Haven, CT, Yale University Press.

Greenwood, Jeremy and Sanchez, Juan and Wang, Cheng (2013), Quantifying the Impact of Financial Development on Economic Development. Review of Economic Dynamics 16, 194-215.

Hasanov, Fakhri, and Fariz Huseynov (2013), Bank Credits and Non-Oil Economic Growth: Evidence from Azerbaijan, International Review of Economics \& Finance 27, 597-610.

Husain, Aasim, Tazhibayeva, Kamilya, and Anna Ter-Martirosyan (2008), Fiscal Policy and Economic Cycles in Oil-Exporting Countries, IMF Working paper 08/253, Washington DC. 
ANYANWU, GAN, HU Financial Intermediation and Growth

Kireyev, Alexei (2000), Comparative Macroeconomics Dynamics in the Arab World: A Panel VAR Approach. IMF Working Paper/00/54, International Monetary Fund.

Kireyev, Alexei (1998), Key Issues Concerning Non-Oil Sector Growth. IMF (ed.), Saudi Arabia's Recent Economic Developments and Selected Issues. Washington, DC, IMF, 2933.

Kumah, Francis and John, Matovu (2005), Commodity Price Shocks and the Odds on Fiscal Performance: A Structural VAR Approach, IMF Working Paper 05/171 (Washington: International Monetary Fund)

Kletzer, Kenneth, and Pranab Bardhan (1987), Credit Markets and Patterns of International Trade, Journal of Development Economics 27(1), 57-70.

Levine, Ross (1997), Financial Development and Economic Growth: Views and Agenda. Journal of Economic Literature, 35(2), 688-726.

McKinnon, Ronald (1973), Money and Capital in Economic Development. (Washington: The Brookings Institution).

Loayza, Norma and Ranciere, Romain (2006), Financial Development, Financial Fragility and Growth. Journal of Money, Credit and Banking 38(4), 1051-1076.

Mirzaei, Ali, and Tomoe Moore (2015), Banking Performance and Industry Growth in an OilRich Economy: Evidence from Qatar, The Quarterly Review of Economics and Finance 60, 58-69.

Nili, Masoud, and Mahdi Rastad (2007), Addressing the Growth Failure of the Oil Economies: The Role of Financial Development, The Quarterly Review of Economics and Finance 46, 726-740.

Ngai, Ho (2005), Bank Credit and Economic Growth in Macao, Monetary Authority of Macao. http://www.amcm.gov.mo/publication/quarterly/oct2005/bank.credit en.pdf. Accessed on April 27, 2015.

Papadavid, Phyllis, Rewilak, Johan and Brighty, Natalie (2017), Financial Barriers to Economic Growth in Low Income Countries. Research in Context, Growth Research Program. $\quad$ http://degrp.squarespace.com/reflections/2017/4/28/financial-barriers-toeconomic-growth. Accessed on November 10, 2017.

Pesaran, Hashem (2004), General Diagnostic Tests for Cross Section Dependence in Panels. University of Cambridge, Faculty of Economics, Cambridge Working Papers in Economics No. 0435.

Patrick, Hugh (1966), Financial Development and Economic Growth in Underdeveloped Countries, Economic Development and Cultural Change 14(2), 174-189.

Pedroni, Peter (2004), Panel Cointegration: Asymptotic and Finite Sample Properties of Pooled Time Series Tests with an Application to the PPP Hypothesis. Econometric Theory 3, 579-625. 
Pedroni, Peter (2000), Fully Modified OLS for Heterogeneous Cointegrated Panels. Advances in Econometrics 15, 93-130.

Pedroni, Peter (2001), Purchasing Power Parity Tests in Cointegrated Panels. Review of Economics and Statistics 83, 727-731.

Pesaran, Hashem, Yongcheol, Shin and Ron, Smith (1999), Pooled Mean Group Estimation of Dynamic Heterogeneous Panels. Journal of the American Statistical Association 94, 621-634.

Rajan, Raghuram, and Luigi Zingales (1998), Financial Dependence and Growth, American Economic Review 88(3), 559-86.

Samargandi, Nahla, Jan, Fidrmuc and Sugata, Ghosh (2014), Financial Development and Economic Growth in an Oil-rich Economy: The Case of Saudi Arabia. Economic Modelling 43, 267-278.

Shaw, Edward (1973), Financial Deepening in Economic Development. (New York: Oxford University Press)

Shan, Jordan and Qi, Jianhong (2006), Does Financial Development Lead to Economic Growth? The case of China. Annals of Economics and Finance 1, 231-250.

Treichel, Volker (1999), Stance of Fiscal Policy and Non-Oil Economic Growth. Oman Beyond the Oil Horizon: Policies Toward Sustainable Growth. Washington, DC. IMF 267.

Uddin, Gazi Salah, Sjö, Bo and Shahbaz, Muhammed (2013), The Causal Nexus Between Financial Development and Economic Growth in Kenya. Economic Modelling, 35, 701707.

Westerlund, Joakim (2007), Testing for Error Correction in Panel Data. Oxford Bulletin of Economics and Statistics 69, 709-748. 